\title{
Proposed OHTC Formula for Subsea Pipelines Considering Thermal Conductivities of Multi-Layered Soils
}

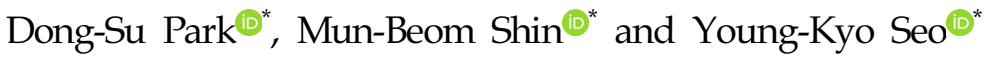 \\ "Department of Ocean Engineering, Korea Maritime and Ocean University, Busan, Korea \\ 다층 지반의 열전도율을 고려한 해저배관의 총괄열전달계수식 제안

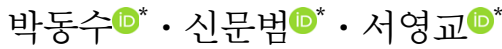 \\ "한국해양대학교 해양공학과
}

KEY WORDS: OHTC(Overall heat transfer coefficient) 총괄열전달계수, Heat loss 열손실, Multi-layered soils 다층 지반, Fourier's law 푸리에 열전도법칙, Thermal conductivity 열전도율

\begin{abstract}
Subsea pipelines are designed to transport mixtures of oil, gas, and their associated impurities from a wellhead that can be in excess of approximately $100{ }^{\circ} \mathrm{C}$, while the external temperature may be approximately $5{ }^{\circ} \mathrm{C}$. Heat can be lost from a subsea pipeline containing a high-temperature fluid to the surrounding environment. It is important that the pipeline be designed to ensure that the heat loss is small enough to maintain sufficient flow from the unwanted deposition of hydrate and wax, which occurs at a critical temperature of about $40{ }^{\circ} \mathrm{C}$. Therefore, it is essential to estimate the heat loss of a subsea pipeline in various circumstances. In previous studies, overall heat transfer coefficient(OHTC) formulas were considered only for a single soil type. Thus, it is difficult to characterize the OHTC of the actual seabed with multiple soil layers. In this paper, an OHTC formula that considers multi-layered soils is proposed for more precise OHTC estimation.
\end{abstract}

\section{Nomenclature}

$\alpha_{0} \quad$ 배관의 매립깊이에 따라 달라지는 보조 기하학적인 양 [-]

$A \quad$ 해저지반 단위면적 $\left[\mathrm{m}^{2}\right]$

$A_{p a r} \quad$ 열에 관한 보조의 기하학적인 양 [-]

$B i_{g} \quad$ 지반의 비오트 수 [-]

$B i_{p} \quad$ 배관의 비오트 수 [-]

$\triangle x_{i} \quad$ 다층 지반에서 지반층의 두께 [m]

$D_{e x t}$ 단일 배관 및 단열재로 보강된 배관의 최 외경 [m]

$D_{i n t} \quad$ 배관 내경 $[\mathrm{m}]$

$D_{r e f} \quad$ 총괄열전달계수 산정을 위한 참조 직경 [m]

$D_{\text {soil } \quad ~} h_{\text {soil }}$ '과 동등한 열 저항을 주기위한 훍의 영향반경 [m]

$D_{\text {steel }} \quad$ 단열재를 제외한 배관의 외경 [m]

$e \quad$ ' $h_{a m b}$ '와 동등한 열저항을 주기위한 훍의 두께 [m]

$H$ 해저지반으로부터 매립된 해저배관 중심까지의 깊이 [m] $h_{a m b}$ 매립정도에 따른 외부유체의 임의의 경막계수 $\left[\mathrm{W} / \mathrm{m}^{2} \mathrm{~K}\right]$

$h_{\text {buried }}$ ' $U_{\text {buried }}$ ' 계산 시 사용하는 해저배관의 내부경막계수, 배관벽의 열전달계수, 해저지반의 열전달계수를 혼합 한 열전달계수 $\left[\mathrm{W} / \mathrm{m}^{2} \mathrm{~K}\right]$

$h_{\text {ground }}$ ' $U_{\text {ground }}$ ' 계산 시 사용하는 해저배관의 내부경막계수, 배관벽의 열전달계수 그리고 해저지반의 열전달계수 를 혼합한 열전달계수 $\left[\mathrm{W} / \mathrm{m}^{2} \mathrm{~K}\right]$

$h_{e x t}$ 배관 외부의 열전달계수 $\left[\mathrm{W} / \mathrm{m}^{2} \mathrm{~K}\right]$

$h_{i n t}$ 배관 내부의 열전달계수 $\left[\mathrm{W} / \mathrm{m}^{2} \mathrm{~K}\right]$

$h_{\text {layer ' }} U_{\text {ground }}$ ' 계산 시 사용하는 해저배관의 내부경막계수, 배관벽의 열전달계수 그리고 다층 지반의 열전달계수 를 혼합한 열전달계수 $\left[\mathrm{W} / \mathrm{m}^{2} \mathrm{~K}\right]$

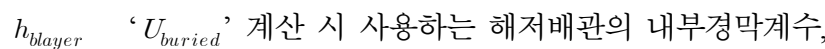
배관벽의 열전달계수 그리고 다층 지반의 열전달계수 를 혼합한 열전달계수 $\left[\mathrm{W} / \mathrm{m}^{2} \mathrm{~K}\right]$ 해저지반의 열전달계수 $\left[\mathrm{W} / \mathrm{m}^{2} \mathrm{~K}\right]$

Received 1 November 2017, revised 5 February 2018, accepted 12 April 2018

Corresponding author Young-Kyo Seo: +82-51-410-4683, yseo@kmou.ac.kr ORCID: https://orcid.org/0000-0002-8838-113X It is noted that this paper is revised edition based on proceedings of KMRTS 2017 in Pangyo.

(c) 2018, The Korean Society of Ocean Engineers

This is an open access article distributed under the terms of the creative commons attribution non-commercial license (http://creativecommons.org/licenses/by-nc/3.0) which permits unrestricted non-commercial use, distribution, and reproduction in any medium, provided the original work is properly cited. 


\begin{tabular}{|c|c|}
\hline$k_{a m b}$ & 외부유체의 열전도율 [W/mK] \\
\hline$k_{f}$ & 배관내부유체의 열전도율 [W/mK] \\
\hline$k_{i}$ & 다층 지반에서 해당 층의 열전도율 [W/mK] \\
\hline$k_{\text {equiv }}$ & 다층 지반을 고려한 등가열전도율 [W/mK] \\
\hline$k_{\text {soil }}$ & 단일 해저지반의 열전도율 $[\mathrm{W} / \mathrm{mK} W / m K]$ \\
\hline$\dot{m}$ & 해저배관 내부 질량 흐름율 $[\mathrm{kg} / \mathrm{s}]$ \\
\hline$Q$ & 열 전달율 [W] \\
\hline$R_{i n t}$ & $\begin{array}{l}\text { 해저배관 내벽에 관내 유동의 대류에 의한 열 저항 } \\
{\left[\mathrm{m}^{2} \mathrm{~K} / \mathrm{W}\right]}\end{array}$ \\
\hline$R_{\text {wall }}$ & $\begin{array}{l}\text { 해저배관 내벽에서 배관외벽으로 전도에 의한 열 저항 } \\
{\left[\mathrm{m}^{2} \mathrm{~K} / \mathrm{W}\right]}\end{array}$ \\
\hline$R_{e x t}$ & 배관 외벽에서 유동의 대류에 의한 열 저항 [ $\left.\mathrm{m}^{2} \mathrm{KW}\right]$ \\
\hline$T$ & 다층 지반 층별 경계면에서의 온도 [K] \\
\hline$U$ & 총괄열전달계수 $\left[\mathrm{W} / \mathrm{m}^{2} \mathrm{~K}\right]$ \\
\hline$U_{\text {buried }}$ & 완전히 매립된 해저배관의 총괄열전달계수 $\left[\mathrm{W} / \mathrm{m}^{2} \mathrm{~K}\right]$ \\
\hline$U_{\text {unburied }}$ & 매립되지 않은 해저배관의 총괄열전달계수 [W/m² $\mathrm{K}]$ \\
\hline$U_{\text {ground }}$ & $\begin{array}{l}\text { 해저지반과 부분 매립된 해저배관의 열전달계수 } \\
{\left[\mathrm{W} / \mathrm{m}^{2} \mathrm{~K}\right]}\end{array}$ \\
\hline$U_{\text {wall }}$ & $\begin{array}{l}\text { 단일 해저배관 벽 및 단열재로 보강된 해저배관 벽의 } \\
\text { 열전달계수 }\left[\mathrm{W} / \mathrm{m}^{2} \mathrm{~K}\right]\end{array}$ \\
\hline$U_{i n t+\text { wall }}$ & |수 및 열전달계수로 ㅇ \\
\hline
\end{tabular}

\section{1. 서 론}

해양플랜트 성장과 심해저 자원의 채굴기술이 발전됨에 따라 심해저의 석유 및 천연가스 수송을 위한 해저배관의 수요가 증 가하며 수송 시 열운용(Thermal management) 및 유동 안정성 (Flow assurance) 문제가 연구 주제로 부상하고 있다. 해저배관은 가동 중 온도가 $40^{\circ} \mathrm{C}$ (극한온도) 이하로 떨어지게 되면 고상염 (Hydrate)및 왁스(Wax) 등으로 운용을 일시적으로 중지(Shut down)하게 되는데 이는 엄청난 경제적 손실을 초래한다.

최근 셧다운 시 해저배관의 온도변화에 대한 연구 $(\mathrm{Xu}$ et al., 2010)가 진행되었고 이러한 온도변화(열손실)에 의한 고상염 및 왁스생성을 예방하기 위해서는 해저배관의 총괄열전달 계수를 토대로 해저배관의 단열설계를 해야 한다. 총괄열전달계수는 해 저배관과 해저배관주위의 해저지반 그리고 해수의 열전도율에 따라 달라지므로 이들 각각의 열전도율로 인한 총괄열전달계수 의 이해가 필요하다. 해저배관의 고상염 및 왁스의 생성방지를 위해 파이프 외벽에 Solid polypropylene, Polypropylene foam 그 리고 Polyurethane 등을 다층으로 제작하는 PIP(Pipe-in-pipe) System, DEH(Direct electric heating) system 등 여러 가지 단열방 법이 연구 및 개발되고 있다(Bai and Bai, 2005). 그러나 경제적 이며 보편적인 단열방법은 Trenching and Backfilling 방법으로, 해저지반에 해저배관이 설치될 가이드라인을 굴착하여 해저배 관을 놓은 후 그 위를 뒤채움 휡(Backfill)으로 덮는 것이다. 후자 의 방법에 관한 연구로는 수치해석을 통한 매립된 해저배관의 환경에 따른 온도분포에 대한 연구(Bai and Niedzwecki, 2014)가 있다. 또한 매립된 해저배관의 총괄열전달계수 산정을 위한 이
론식 연구가 진행되어 왔으며 이론식들은 해수와 해저지반의 경 계면 및 해저배관 외벽면의 경계조건을 수정하여 제안하였다.

먼저 등온의 조건 즉 디리클레(Dirichlet) 경계조건을 가정한 Carslaw and Jaeger 이론식(Carslaw and Jaeger, 1959)이 제안되었 다. 다음으로 해수와 해저지반의 경계면은 Carslaw and Jaeger 이 론식과 같이 디리클레 경계조건을 가정하지만 해저배관 외벽은 혼합(Mixed)경계조건을 가정하는 Morud and Simonsen 이론식 (Morud and Simonsen, 2007)이 제안되었다. 그리고 해수 및 해저 지반의 경계면과 해저배관 외벽면의 경계조건을 모두 혼합경 계조건으로 가정한 Ovuworie 이론식(Ovuworie, 2010)이 제안되 었고 최근 Ovuworie 이론식을 일부 수정한 Zakarian 이론식 (Zakarian et al., 2012)이 제안되었다. Zakarian 이론식의 경우 모 형실험(Oh et al., 2014)에 의해 검증이 실시되었다.

지금까지 제안되었던 이론식들은 총괄열전달계수 계산을 위 한 지반을 열전도율이 일정한 단일 지반으로 간주하였다. 하지 만 실제 해저지반은 다층 지반으로 구성되어있으며 해저면에서 아래로 깊이가 증가함에 따라 함수비 등 여러 가지 요인으로 인하여 열전도율이 달라진다. 따라서 본 연구에서는 실제 해저 지반과 같은 각 지반 층의 열전도율이 다른 다층 지반에 해저 배관이 매립되었을 때의 총괄열전달계수를 Zakarian 이론식 (Zakarian et al., 2012)을 변형하여 다층 지반을 고려 할 수 있게 제안하고자 한다. 다층지반의 등가열전도율을 산정하는 식은 Kelvin의 선형 열원모델(Line source model)을 응용한 식이 제안 되었다(Yoon et al., 2014). 하지만 이는 지면에 수직으로 관입된 보어홀의 열전달에 의해 산정되는 식이며 해저지반과 수평으로 일부 매립 혹은 완전 매립된 해저배관에 적용하기 힘들다. 따라 서 본 연구에서는 다층판에서의 Fourier 열전도법칙을 응용하여 산정한 등가열전도율 식을 다층지반을 고려한 총괄열전달계수 제안 식에 적용하였다. 제안 식은 수치해석과 비교하여 검토하 였으며 해저지반의 열전도율은 Hamdham and Clarke(2010) 그리 고 Park and $\mathrm{Seo}(2017)$ 의 연구를 참고하였다.

\section{2. 선행연구 검토}

\section{1 총괄열전달계수 개념}

총괄열전달계수는 고체 벽을 두고 고온유체에서 저온유체로 열이 전달되는 경우의 모든 전열저항을 고려한 총괄적인 열전 달 계수이다. Fig. 1 과 같이 매립되지 않은 해저배관의 총괄열전 달계수 $\left(U_{\text {unburied }}\right)$ 는 다음과 같다.

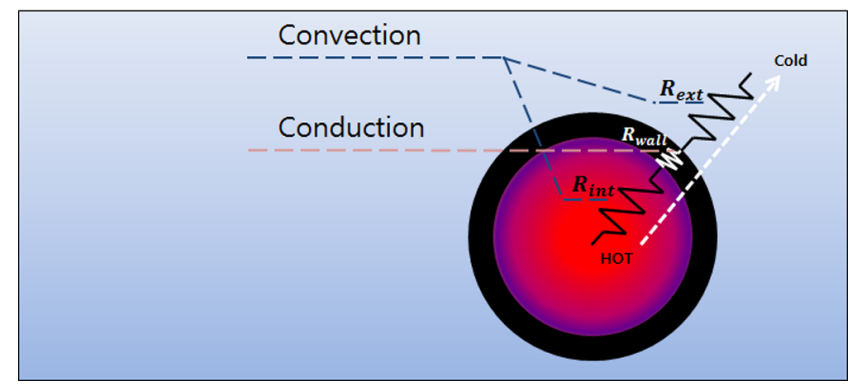

Fig. 1 Thermal resistances of an unburied subsea pipeline 
해저배관 내벽에서 관내 유동의 대류에 의한 열 저항 $R_{i n t}$, 해 저배관내벽에서 해저배관외벽으로 전도에 의한 열 저항 $R_{\text {wall }}$ 그리고 해저배관 외벽에서 유동의 대류에 의한 열 저항 $R_{e x t}$ 의 영향을 고려해 식 (1)과 같이 나타낼 수 있다.

$$
U_{\text {unburied }}=\frac{1}{D_{\text {ref }}\left(R_{\text {int }}+R_{\text {wall }}+R_{\text {ext }}\right)}
$$

\section{2 해저배관 총괄열전달계수 이론식}

부분적으로 매립되었거나, 완전히 매립된 해저배관의 총괄열 전달계수 $(U)$ 는 식 (2)와 같으며 여기서 해저배관이 해수에 노 출된 정도를 나타내는 $\theta_{b}$ 는 Fig. 2 와 같다(Bai and Bai, 2005).

$$
U=\left\{\begin{array}{cl}
\frac{\theta_{b}}{\pi} U_{\text {unburied }}+\left(1-\frac{\theta_{b}}{\pi}\right) U_{\text {ground }} & \text { if }-\frac{\text { Dext }}{2} \leq H<\frac{\text { Dext }}{2} \\
U_{\text {buried }} & \text { if } \quad \frac{\text { Dext }}{2} \leq H
\end{array}\right.
$$

기존 해저배관의 총괄열전달계수 이론식들은 식 (2)에서 해저

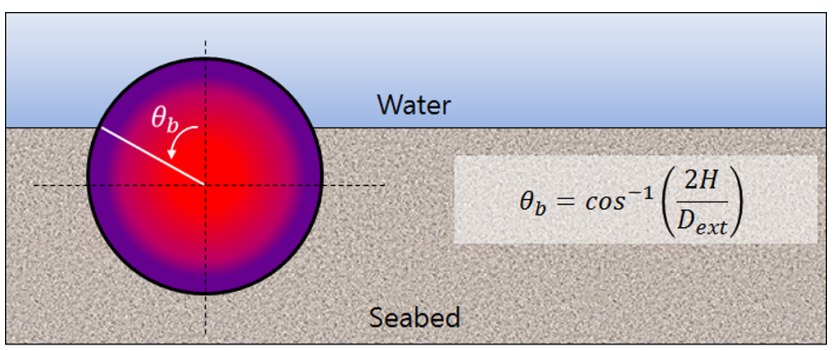

Fig. 2 Angle of a exposed surface of a subsea pipeline

배관이 부분적으로 매립되었을 때의 $U_{g r o u n d}$, 완전히 매립되었 을 때의 $U_{b u r i e d}$ 을 정의하였으며 대표적인 이론식들은 Table 1 과 같다. Table 1 과 같이 기존 이론식들은 지반을 단일 지반 즉 하 나의 열전도율 $\left(k_{\text {soil }}\right)$ 을 가지는 지반으로 가정하였다. 본 연구에 서는 각각 다른 열전도율 $\left(k_{1}, k_{2}, k_{3} \cdots\right)$ 로 구성된 다층 지반을 하나의 등가열전도율 $\left(k_{\text {equiv }}\right)$ 로 치환하였다. 그리고 기존 이론식 중 수치해석(Zakarian et al., 2012) 및 실내모형실험(Oh et al., 2014)으로 그 정확도가 검증된 Zakarian 이론식의 단일지반 열 전도율 $k_{\text {soil }}$ 을 $k_{\text {equiv }}$ 로 변환 및 조건을 추가하여 다층지반을 고 려한 총괄열전달계수 식을 제안하고자 한다.

Table 1 Overall heat transfer coefficient formulas

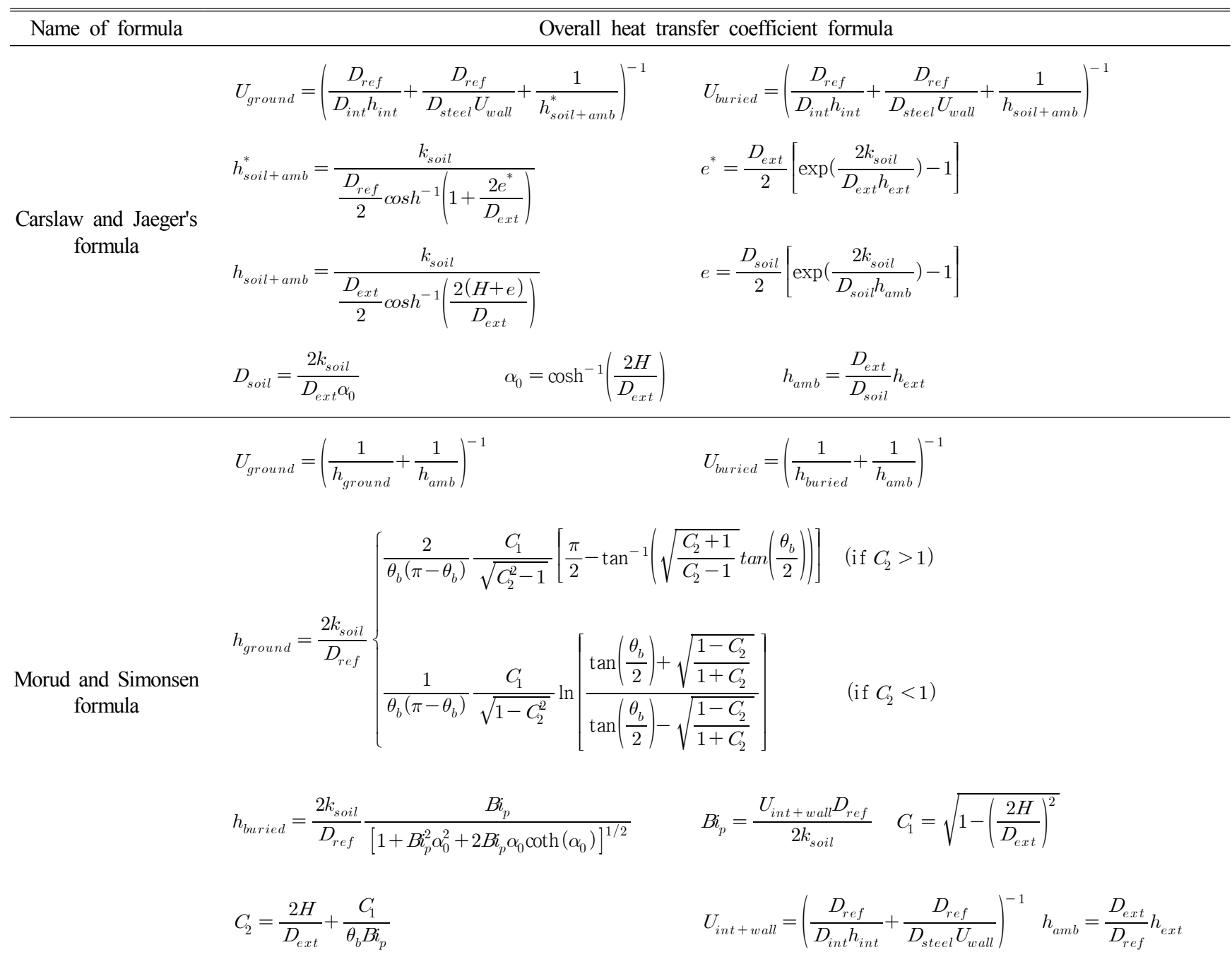


Table 1 Overall heat transfer coefficient formulas (Continued)

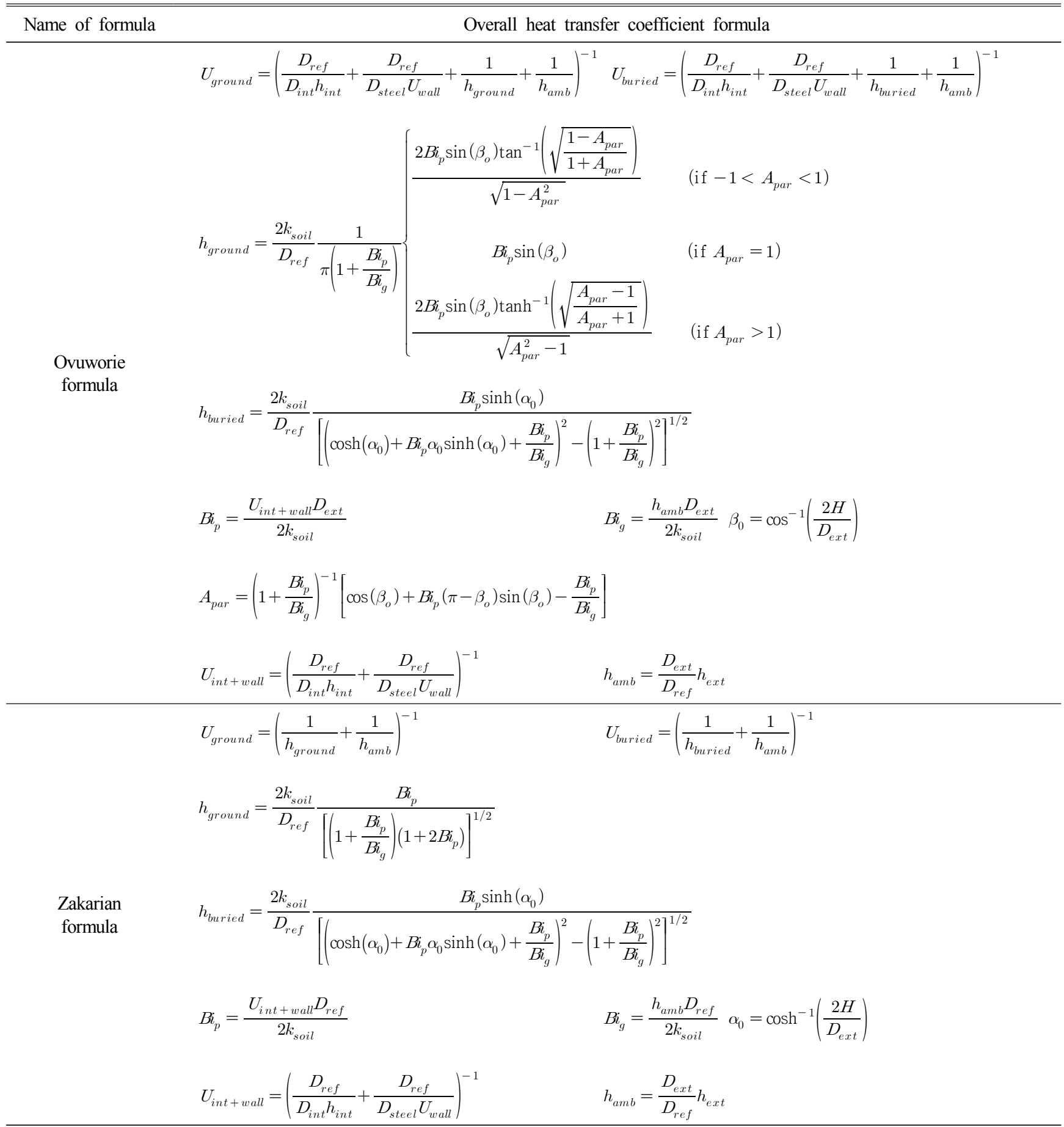

\section{3. 다층 지반을 고려한 총괄열전달계수 제안 식}

다층 지반의 각각 다른 열전도율을 등가열전도율로 치환하기 위하여 Fourier의 열전도법칙을 적용하여 Fig. 3과 같은 각지반 층의 다른 열전도율을 Fig. 4와 같은 등가열전도율로 치환하였다.

\subsection{Fourier의 열전도법칙}

물체에 온도구배가 존재한다면 높은 온도에서 낮은 온도로 에너지가 이동하게 된다. 여기서 온도구배에 의한 열 전달율

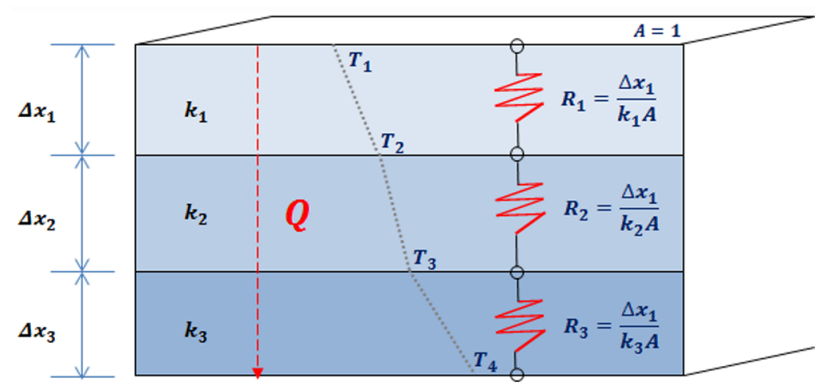

Fig. 3 Heat transfer through a multi-layered plates 


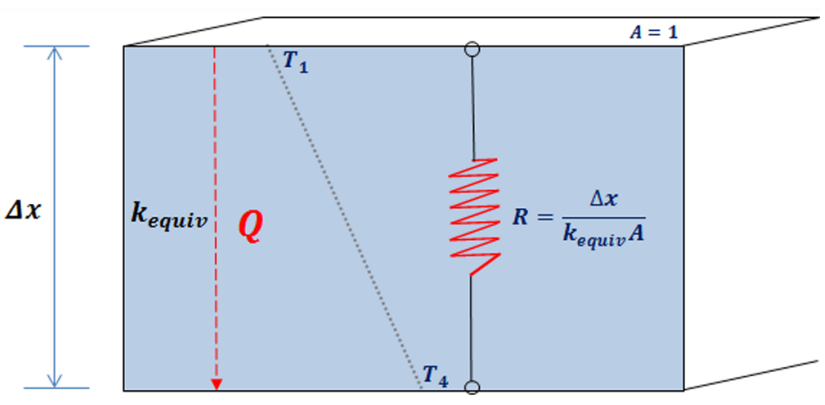

Fig. 4 Equivalent thermal conductivity of multi-layered plates

(Heat transfer rate)은 식 (3)과 같이 나타내며 이를 Fourier의 열 전도 법칙이라 한다(Holman, 2009).

$$
Q_{x}=-k A \frac{\partial T}{\partial x}
$$

식 (3)을 토대로 Fig. 3과 같이 각각 다른 열전도율로 구성된 지반 층의 단위면적당 $\left(A=1 \mathrm{~m}^{2}\right)$ 열 전달율을 고려하여 열 저항 과의 관계식을 도출하면 식 (4)와 같으며 이때 각 층에 작용하 는 열 전달율 $(Q)$ 은 동일하다.

$$
Q=\frac{T_{2}-T_{1}}{R_{1}}=\frac{T_{3}-T_{2}}{R_{2}}=\frac{T_{4}-T_{3}}{R_{3}}
$$

또한 식 (4)는 식 (5)와같이 정의할 수 있다.

$$
Q=-k_{1} \frac{T_{2}-T_{1}}{\Delta x_{1}}=-k_{2} \frac{T_{3}-T_{2}}{\Delta x_{2}}=-k_{3} \frac{T_{4}-T_{3}}{\Delta x_{3}}
$$

식 (5)의 세 식의 관계를 고려한 열 전달율은 식 (6)과 같이 나타낼 수 있다.

$$
Q=\frac{T_{4}-T_{1}}{\frac{\Delta x_{1}}{k_{1}}+\frac{\triangle x_{2}}{k_{2}}+\frac{\Delta x_{3}}{k_{3}}}
$$

\section{2 해저지반 등가열전도율 산정}

Fig. 3과 같이 각각 다른 열전도율을 가지는 다층으로 구성된 해저지반의 열전도율을 Fig. 4와 같이 하나의 열전도율로 나타 내기 위해 열 전달율을 식 (7)과 같이 정의하였다.

$$
Q=\frac{T_{4}-T_{1}}{R}=-k_{\text {equiv }} \frac{T_{4}-T_{1}}{\triangle x}
$$

등가열전도율은 식 (6)과 식 (7)의 관계에 의해 다음과 같이 식 (8)로 정의할 수 있다.

$$
k_{\text {equiv }}=\frac{\Delta x}{\frac{\Delta x_{1}}{k_{1}}+\frac{\Delta x_{2}}{k_{2}}+\frac{\Delta x_{3}}{k_{3}}}
$$

위에서 정의한 내용을 바탕으로 2 개 이상의 지반 층이 존재할 때 열전도율은 다음과 같이 정의하였다.

$$
k_{\text {equiv }}=\frac{\sum_{i=1}^{n} \Delta x_{i}}{\sum_{i=1}^{n} \frac{\Delta x_{i}}{k_{i}}}
$$

\section{3 다층 지반을 고려한 해저배관 총괄열전달계수 제안}

본 연구에서는 Zakarian 이론식을 토대로 수정하여 제안하고 자 하며 이를 Proposed formula로 명명하였다. Proposed formula 는 Zakarian 이론식의 단일지반 열전도율 항 $\left(k_{\text {soil }}\right)$ 을 등가열전도 율 $\left(k_{\text {equiv }}\right)$ 로 변환하고 다층지반의 범위를 정하였다.

해저배관이 부분적으로 매립되었을 때의 $U_{\text {ground }}$ 는 식 (10), 완전히 매립되었을 때의 $U_{\text {buried }}$ 는 식 (11)과 같다.

$$
\begin{aligned}
& U_{\text {ground }}=\left(\frac{1}{h_{\text {layer }}}+\frac{1}{h_{\text {amb }}}\right)^{-1} \\
& U_{\text {buried }}=\left(\frac{1}{h_{\text {blayer }}}+\frac{1}{h_{\text {amb }}}\right)^{-1}
\end{aligned}
$$

식 (10)과 식 (11)에서 해저배관내부 경막계수, 파이프 벽의 열전달계수 그리고 다층 지반의 열전달계수를 결합한 $h_{\text {layer }}$ 와 $h_{\text {blayer }}$ 은 다음과 같이 각각 식 (12)와 식 (13)과 같다.

$$
h_{\text {layer }}=\frac{2 k_{\text {equiv }}}{D_{\text {ref }}} \frac{B i_{p}}{\left[\left(1+\frac{B i_{p}}{B i_{g}}\right)\left(1+2 B i_{p}\right)\right]^{1 / 2}}
$$

$h_{\text {blayer }}=\frac{2 k_{\text {equiv }}}{D_{\text {ref }}}$

$$
\times \frac{B i_{p} \sinh \left(\alpha_{0}\right)}{\left[\left(\cosh \left(\alpha_{0}\right)+B i_{p} \alpha_{0} \sinh \left(\alpha_{0}\right)+\frac{B i_{p}}{B i_{g}}\right)^{2}-\left(1+\frac{B i_{p}}{B i_{g}}\right)^{2}\right]^{1 / 2}}
$$

식 (12)와 식 (13)의 $B i_{p}$ 와 $B i_{g}$ 는 해저배관과 해저지반의 비오 트 수(Biot number) 이며 식 (14) 및 식 (15)와 같다.

$$
B i_{p}=\frac{U_{\text {int }+ \text { wall }} D_{\text {ref }}}{2 k_{\text {equiv }}}
$$

$$
B i_{g}=\frac{h_{a m b} D_{r e f}}{2 k_{\text {equiv }}}
$$

$$
\alpha_{0}=\cosh ^{-1}\left(\frac{2 H}{D_{e x t}}\right)
$$

식 (16)의 $\alpha_{0}$ 는 해저배관의 매립깊이에 따라 달라지는 보조 
기하학적인 양이며, 식 (17)은 해저배관 내부의 경막계수 그리 고 해저배관 벽의 열전달계수를 혼합한 열전달계수이다.

$$
U_{\text {int }+ \text { wall }}=\left(\frac{D_{\text {ref }}}{D_{\text {int }} h_{\text {int }}}+\frac{D_{\text {ref }}}{D_{\text {steel }} U_{\text {wall }}}\right)^{-1}
$$

또한 해저배관 외부의 경막계수는 식 (18)과 같다.

$$
h_{a m b}=\frac{D_{e x t}}{D_{r e f}} h_{e x t}
$$

식 (19)는 앞서 식 (9)와 같이 Fourier의 열전도 법칙을 다층판 에 적용한 개념을 다양한 열전도율을 가지는 다층지반에 응용 하여 정의된 등가열전도율이다. 등가열전도율을 적용할 다층지 반의 범위는 식 (20)과 같으며 다층지반의 범위는 매립깊이 $(H)$ 에 따라 $D_{e x t}$ 와 $\alpha$ 의 조합으로 구성된다.

$$
\begin{aligned}
& k_{\text {equiv }}=\frac{\Delta x}{\sum_{i=1}^{n} \frac{\Delta x_{i}}{k_{i}}} \quad\left(\therefore \Delta x=\sum_{i=1}^{n} \Delta x_{i}\right) \\
& \rightarrow 0 \leq \Delta x \leq D_{e x t}+H \\
& \text { When, } H \leq \frac{D_{e x t}}{2} \\
& \text { When, } H>\frac{D_{e x t}}{2} \text { and } H \leq \frac{2 \alpha_{0}+1.3 D_{e x t}}{2} \\
& \rightarrow 0 \leq \Delta x \leq \frac{2 H+1.3 D_{e x t}+2 \alpha_{0}}{2} \\
& \text { When, } H>\frac{D_{e x t}}{2} \text { and } H>\frac{2 \alpha_{0}+1.3 D_{e x t}}{2} \\
& \rightarrow \frac{2 H-1.3 D_{e x t}-2 \alpha_{0}}{2} \leq \Delta x \leq \frac{2 H+1.3 D_{e x t}+2 \alpha_{0}}{2}
\end{aligned}
$$

\section{4. 수치 해석}

본 연구에서 제안된 Proposed formula를 검토하기 위해 실험 데이터와 비교연구(Huminic and Huminic, 2013; Papukchiev and Buchholz, 2017)로 열전달 해석의 정확성이 검증된 상용수치해 석 프로그램인 ANSYS CFX v13.0을 사용하였다. 해저배관에 일 정온도의 원유를 유입시켜 모델 전체의 온도가 정상상태에 이 르렀을 때 해저배관의 출구, 입구, 해저배관 표면의 수치해석결 과(평균온도)를 이용하여 총괄열전달계수를 산정하고 Proposed formula의 계산결과와 비교 분석하였다.

\section{1 모델링 및 격자생성}

수치해석을 위해 해석영역은 Fig. 5와 같이 모델링 하였다. 본 해석에서는 3차원 모델을 사용하였으며, 격자는 Fig. 6과 같이 해석의 정확도를 높이기 위해 해저배관 주변 격자를 조밀하게

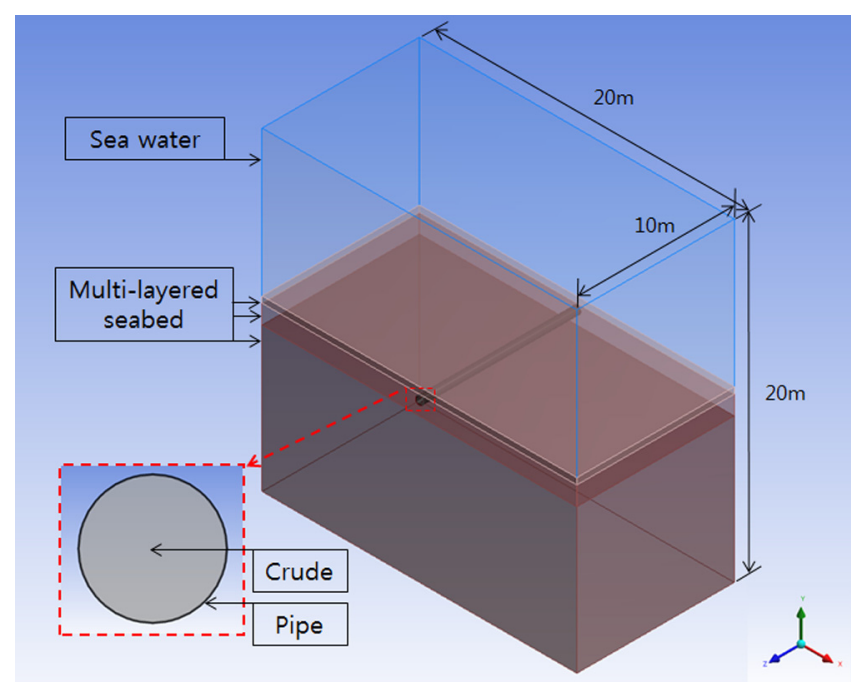

Fig. 5 Characteristics of numerical model

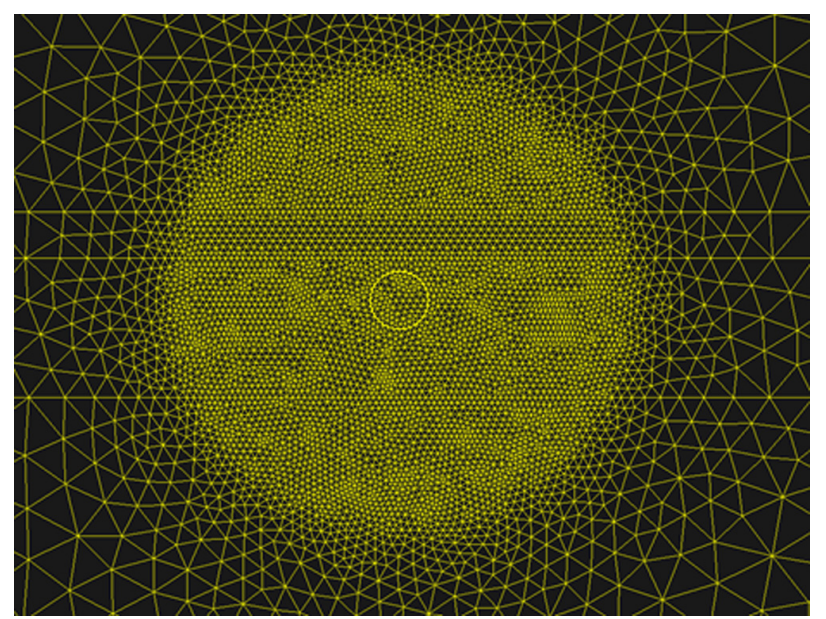

Fig. 6 Grid for numerical analysis

Table 2 Coefficients of turbulent model

\begin{tabular}{ccccccc}
\hline \hline & $\beta^{\prime}$ & $\beta_{1}$ & $\beta_{2}$ & $\sigma_{k}$ & $\sigma_{\omega}$ & $\alpha$ \\
\hline$\Phi_{1}$ & 0.009 & 0.075 & - & 0.5 & 0.5 & $\frac{5}{9}$ \\
$\Phi_{2}$ & 0.009 & - & 0.0828 & 1 & 0.865 & $\frac{\beta}{\beta^{\prime}}-\frac{\sigma_{\omega 2} k^{2}}{\sqrt{\beta^{\prime}}}$ \\
\hline
\end{tabular}

구성하였다. 격자에 대한 영향을 평가하기 위해 격자 의존성 검 사를 수행하였고 온도분포가 정상상태에 이르렀을 때 약 15 만 개의 노드 수에서 격자 의존성이 사라진다고 판단하였다.

\section{2 지배방정식}

정상상태, 비압축성 난류유동으로 지배방정식은 연속방정식 인 식 (21) 그리고 운동량 방정식인 식 (22)와 같다(ANSYS Inc., 2010a).

$$
\frac{\partial \rho}{\partial t}+\frac{\partial\left(\rho U_{j}\right)}{\partial x_{j}}=0
$$




$$
\begin{aligned}
& \frac{\partial\left(\rho U_{j}\right)}{\partial t}+\frac{\partial\left(\rho U_{i} U_{j}\right)}{\partial x_{j}}=-\frac{\partial P}{\partial x_{j}} \\
& +\frac{\partial}{\partial x_{j}}\left[\mu\left(\frac{\partial U_{i}}{\partial x_{j}}+\frac{\partial U_{j}}{\partial x_{i}}\right)-\frac{2}{3} \mu\left(\frac{\partial U_{k}}{\partial x_{k}}\right) \delta_{i j}\right]-\rho\left(\overline{u_{i}^{\prime} u_{j}^{\prime}}\right)
\end{aligned}
$$

위 식처럼 시간 평균화된 Navier-Stokes 방정식은 Reynolds 응력 즉, $-\rho\left(\overline{u_{i}^{\prime} u_{j}^{\prime}}\right)$ 항이 추가적으로 포함된다. 경계층 근처의 결과 를 확인하기 위해서는 $k-\omega$ 모델이 적합하지만 벽면에서 멀어질 수록 수렴성이 떨어진다는 단점이 있고 벽면에서 충분이 떨어 진 자유유동에는 $k-\epsilon$ 모델이 적합하지만 벽면 부근의 예측은 부정확하다. 따라서 본 연구에서 난류모델은 $k-\epsilon$ 모델과 $k-\omega$ 모델의 장점을 결합한 $k-\omega S S T$ (Shear stress transport) 모델을 적 용하였다. $k-\omega S S T$ 모델은 혼성함수인 $F_{1}$ 을 이용하여 $k-\omega$ 모델 과 $F_{1}$ 을 곱하고, $k-\epsilon$ 모델에는 $\left(1-F_{1}\right)$ 을 곱하여 $k-\omega$ 형태로 다 시 쓰면 식 (23) 및 식 (24)와 같다. 여기서 벽면 근처에서는 $F_{1}=0$ 로 $k-\omega$ 모델, 자유유동에서는 $F_{1}=1$ 로 $k-\epsilon$ 모델이 된다 (ANSYS Inc., 2010a).

$$
\begin{aligned}
& \frac{\partial(\rho k)}{\partial t}+\frac{\partial\left(\rho k U_{j}\right)}{\partial x_{j}}= \\
& \tau_{i j} \frac{\partial U_{j}}{\partial x_{j}}+\frac{\partial}{\partial x_{j}}\left[\left(\mu+\sigma_{k} \mu_{t}\right) \frac{\partial k}{\partial x_{j}}\right]-\beta^{\prime} \rho \omega k \\
& \frac{\partial(\rho \omega)}{\partial t}+\frac{\partial\left(\rho \omega U_{j}\right)}{\partial x_{j}}= \\
& \frac{\partial \omega}{k} \tau_{i j} \frac{\partial U_{j}}{\partial} x_{j}+\frac{\partial}{\partial x_{j}}\left[\left(\mu+\sigma_{\omega} \mu_{t}\right) \frac{\partial \omega}{\partial x_{j}}\right] \\
& -\beta \rho \omega^{2}+2\left(1-F_{1}\right) \rho \sigma_{\omega^{2}} \frac{1}{\omega} \frac{\partial k}{\partial x_{j}} \frac{\partial \omega}{\partial x_{j}}
\end{aligned}
$$

각 난류 상수들을 $F_{1}$ 에 의한 식으로 표현하면 식 (25)와 같으 며 $\Phi_{1}$ 은 $k-\epsilon$ 모델, $\Phi_{2}$ 은 $k-\omega$ 모델이며 모델의 상수는 Table 2 와 같다(ANSYS Inc., 2010a).

$$
\Phi=F_{1} \Phi_{1}+\left(1-F_{1}\right) \Phi_{2}
$$

\section{3 초기조건 및 경계조건}

본 연구의 수치해석은 유한체적법(Finite volume method)을 통해 해석을 수행하며, 고해상도기법(High resolution scheme)을 사용하는 ANSYS CFX v13.0을 이용하여 초기조건 및 경계조건 을 설정하였으며 모델의 온도분포가 변하지 않는 정상상태의 해석을 수행하였다(ANSYS Inc., 2010b).

수치해석을 위한 초기조건 및 경계조건은 Fig. 7과 같으며, 모 델의 초기온도는 $4^{\circ} \mathrm{C}$ 로 설정하였다. 해수(Sea water)의 벽면은 점착 조건(No slip wall)로 $4{ }^{\circ} \mathrm{C}$ 의 고정온도를 부여하였으며 입구 (Inlet), 출구(Outlet)의 유속은 $0.05 \mathrm{~m} / \mathrm{s}$ 을 유지시켰다.

원유(Crude)는 API 37.5도의 브렌트유(Brent oil)의 밀도, 점성 계수, 비열 그리고 열전도율을 사용하였으며 입구는 Velocity inlet 그리고 출구는 Velocity outlet 조건으로 유속 $2.5 \mathrm{~m} / \mathrm{s}$ 로 설정 하였고 원유의 입구온도는 $70^{\circ} \mathrm{C}$ 로 설정하였다.

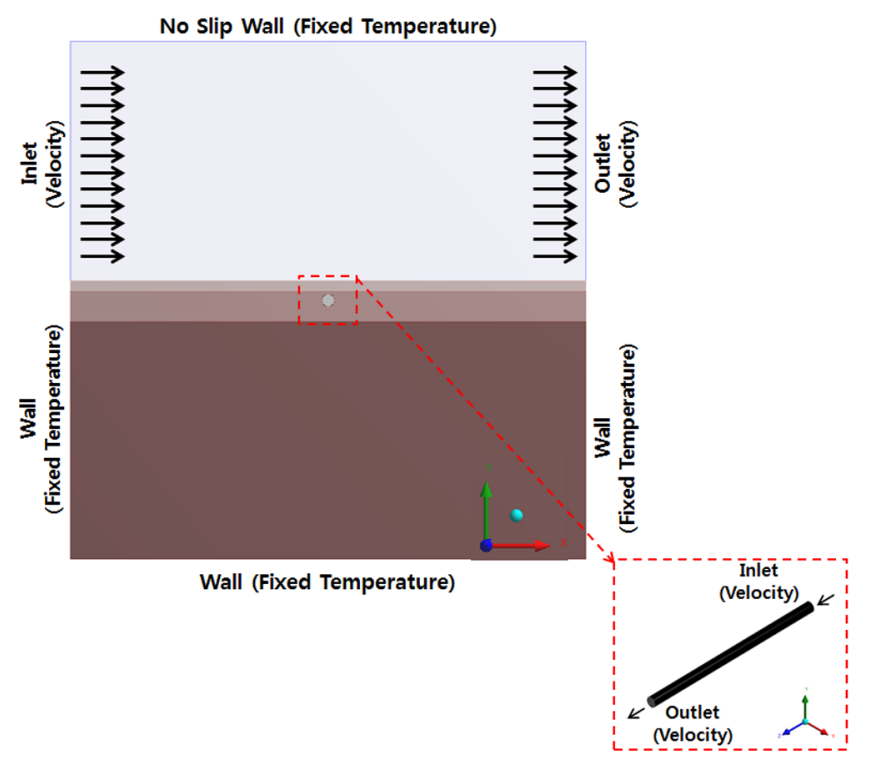

Fig. 7 Boundary condition of numerical model

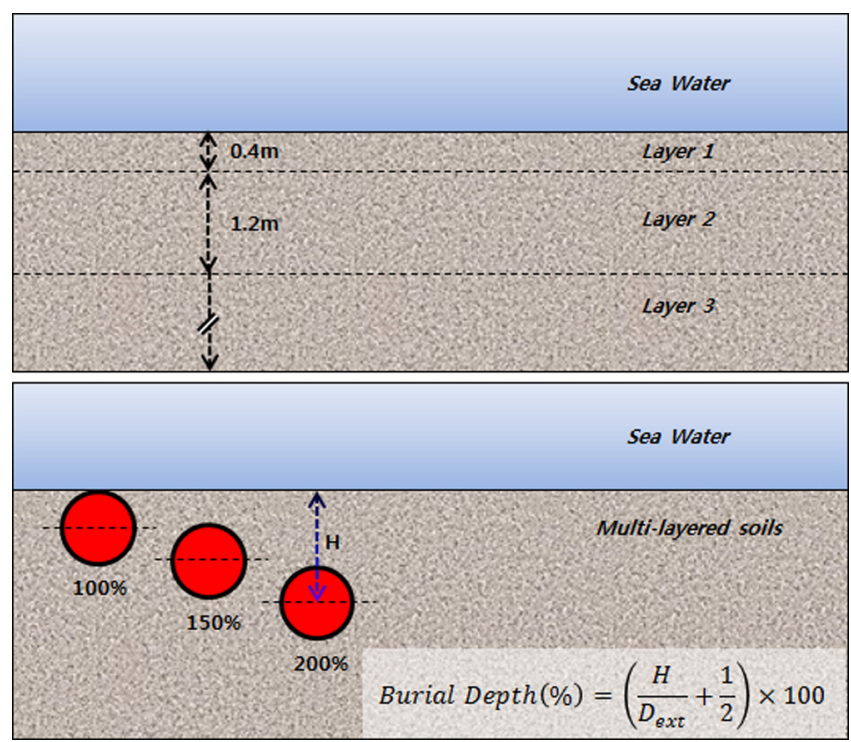

Fig. 8 Organization of multi-layered soils and burial depth

해저배관의 규격은 API(American petroleum institute)의 석유 수송용 강재인 API 5L X52 PSL 2의 규격을 적용하였다. 지반은 Fig. 8과 같은 3 개의 층(Layer)로 모델링 하였으며 각 층의 벽면 은 점착조건을 부여하였고, 각 층의 열전도율은 Hamdham and Clarke(2010) 및 Park and Seo(2017)을 참고하였다.

\section{4 수치해석 결과를 이용한 총괄열전달계수 계산 이론}

식 (26)과 같이 해저배관의 입 출구의 온도구배를 이용해 열 전달율 $Q$ 를 구하였다.

$$
Q=\dot{m} C_{p} \triangle T=\dot{m} C_{p}\left(T_{\text {inlet }}-T_{\text {outlet }}\right)
$$

식 (26)에서 계산한 $Q$ 와 원유의 평균온도 $\left(T_{\text {crude } m}\right)$ 및 해저배 관 표면의 평균온도 $\left(T_{\text {pipewallmm }}\right)$ 를 이용해 식 (27)에 대입하여 
$h_{e x t}$ 와 $h_{i n t}$ 를 계산한다. 여기서 계산된 $h_{e x t}, h_{i n t}$ 를 식 (1)에 대 입하여 총괄열전달계수를 계산하였다.

$$
h=\frac{q}{A\left(T_{\text {crude_m }}-T_{\text {pipewall_m }}\right)}
$$

\section{5. 해석 케이스 및 결과비교}

다층지반을 고려한 매립된 해저배관의 Proposed formula을 검 토하기 위해 케이스 해석을 실시하였다. 먼저 해석 케이스 1 에 서는 다양한 비오트 수를 가지는 해저배관에 대한 해석을 통해 해저배관 종류에 따른 Proposed formula의 적용 가능성을 검토 하였다. 해석 케이스 2 에서는 같은 비오트 수를 가지는 해저배 관을 기준으로 다양한 열전도율 및 층 두께를 가지는 다층지반 에 대해 Proposed formula의 적용가능성을 검토하였다.

\section{1 해석 케이스 1 : 다양한 비오트 수의 해저배관}

해석 케이스 1 은 해저배관 벽의 열전달계수 및 해저지반의 열 전도율에 의해 결정되는 비오트 수를 기준으로 세 가지 해저배 관에 대한 해석을 실시하였다. 해저배관과 총괄열전달계수 그리 고 비오트 수의 관계는 Table 3와 같다(Zakarian et al., 2012).

Table 3 Typical biot number and OHTC by type of pipeline

\begin{tabular}{lcc}
\hline Type of subsea pipeline & $\begin{array}{c}\text { Typical OHTC } \\
{\left[\mathrm{W} / \mathrm{m}^{2} \mathrm{~K}\right]}\end{array}$ & $\begin{array}{c}\text { Typical biot } \\
\text { number }\end{array}$ \\
\hline $\begin{array}{l}\text { PIP system } \\
\text { Insulated pipeline }\end{array}$ & $0.5-15$ & $\begin{array}{c}B i_{p} \leq 4 \\
(\mathrm{Low})\end{array}$ \\
Insulated pipe & $15-50$ & $\begin{array}{c}4<i_{p} \leq 50 \\
(\text { Intermediate })\end{array}$ \\
Concrete weight coated pipeline & $50-1500$ & $\begin{array}{c}50<B i_{p} \\
(\text { High })\end{array}$ \\
Uninsulated pipeline &
\end{tabular}

\subsection{1 높은 비오트 수 해저배관(Uninsulated pipeline)}

높은 비오트 수의 해저배관은 단열재가 없는 해저배관을 토 대로 Proposed formula 계산 및 수치해석을 실시하였다. 본 해저 배관은 비오트 수가 약 146 인 경우로 해저배관의 외경, 내경, 열전도율 그리고 해저지반의 층별 깊이 및 열전도율은 Table 4 와 같다.

Table 4 Properties of high biot number pipe and soils

\begin{tabular}{cccc}
\hline $\begin{array}{c}\text { Subsea pipe } \\
\text { and } \\
\text { multi-layered soils }\end{array}$ & $\begin{array}{c}\text { Subsea pipe } \\
\text { diameter } \\
{[\mathrm{m}]}\end{array}$ & $\begin{array}{c}\text { Depth of } \\
\text { layer } \\
{[\mathrm{m}]}\end{array}$ & $\begin{array}{c}\text { Thermal } \\
\text { conductivity } \\
{[\mathrm{W} / \mathrm{mK}]}\end{array}$ \\
\hline Pipe inner diameter & 0.4826 & - & 51 \\
Pipe outer diameter & 0.508 & - & 1.31 \\
Soil layer 1 & - & $0 \sim 0.4$ & 1.4 \\
Soil layer 2 & - & $0.4 \sim 1.6$ & 1.6 \\
Soil layer 3 & - & $1.6 \sim \infty$ & \\
\hline
\end{tabular}

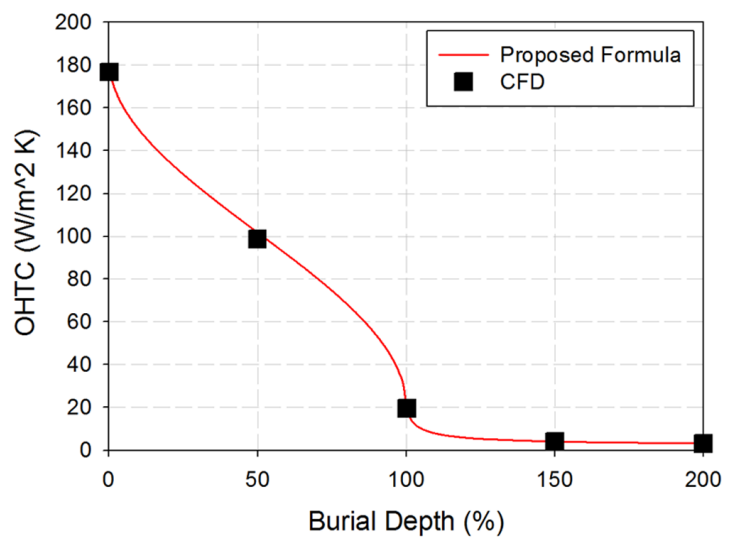

Fig. 10 OHTC result of high biot number of pipe

총괄열전달계수 계산 및 해석결과는 Fig. 10 과 같다. 매립깊이 $0 \%$, 즉 해수에 완전 노출된 해저배관의 총괄열전달계수는 약 $180 \mathrm{~W} / \mathrm{m}^{2} \mathrm{~K}$ 을 나타내었고 매립깊이 $200 \%$ 일 때 총괄열전달계수 는 약 $3 \mathrm{~W} / \mathrm{m}^{2} \mathrm{~K}$ 의 결과를 확인 할 수 있었다. 매립깊이 $0 \%, 50 \%$, $100 \%, 150 \%, 200 \%$ 에서 Proposed formula계산 결과 및 수치해석 결과의 평균오차는 약 $2.4 \%$ 를 나타내었다.

\subsection{2 중간 크기 비오트 수 해저배관(CWC pipeline)}

중간 크기 비오트 수 해저배관은 아스팔트 및 콘크리트를 단 열재로 사용하는 CWC(Concrete weight coated)배관에 대한 계산 및 수치해석을 실시하였다.

Table 5 Properties of intermediate biot number pipe and soils

\begin{tabular}{cccc}
\hline \hline $\begin{array}{c}\text { Subsea pipe } \\
\text { and } \\
\text { multi-layered soils }\end{array}$ & $\begin{array}{c}\text { Subsea pipe } \\
\text { diameter } \\
{[\mathrm{m}]}\end{array}$ & $\begin{array}{c}\text { Depth of } \\
\text { layer } \\
{[\mathrm{m}]}\end{array}$ & $\begin{array}{c}\text { Thermal } \\
\text { conductivity } \\
{[\mathrm{W} / \mathrm{mK}]}\end{array}$ \\
\hline Pipe inner diameter & 0.4826 & - & 51 \\
Pipe outer diameter & 0.508 & - & 0.74 \\
Asphalt & 0.515 & - & 2.9 \\
Concrete & 0.615 & - & 1.31 \\
Soil layer 1 & - & $0 \sim 0.4$ & 1.4 \\
Soil layer 2 & - & $0.4 \sim 1.6$ & 1.6 \\
Soil layer 3 & - & $1.6 \sim \infty$ & \\
\hline
\end{tabular}

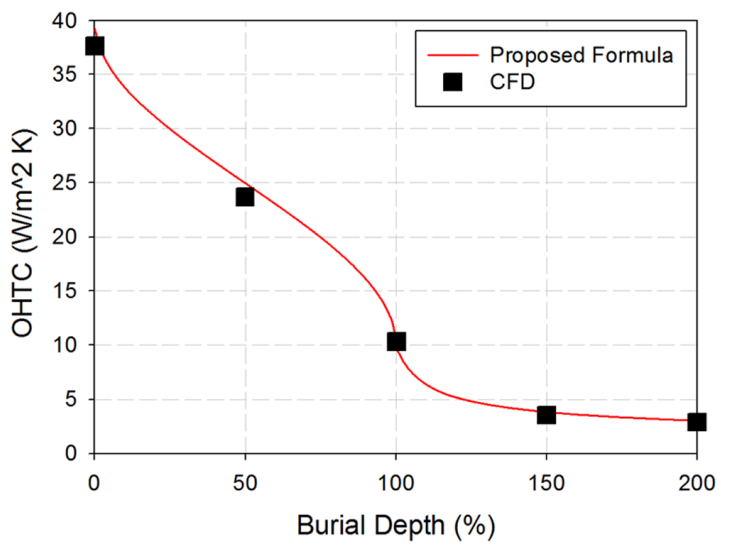

Fig. 11 OHTC result of Intermediate biot number of pipe 
본 해저배관의 비오트 수는 약 9 의 경우이며 해저배관과 단 열재의 외경, 내경, 열전도율 그리고 해저지반의 층별 깊이 및 열전도율은 Table 5에 나타내었다.

총괄열전달계수 계산 및 수치해석 결과는 Fig. 11 과 같이 매립 깊이 $0 \%$ 일 때 약 $40 \mathrm{~W} / \mathrm{m}^{2} \mathrm{~K}$, 매립깊이 $200 \%$ 에서 약 $3 \mathrm{~W} / \mathrm{m}^{2} \mathrm{~K}$ 로 나 타났다. 매립깊이 $0 \%, 50 \%, 100 \%, 150 \%, 200 \%$ 에서 Proposed formula 계산결과 및 수치해석 결과를 비교하였을 때 오차는 약 $5.6 \%$ 정도로 나타났다.

\subsection{3 낮은 비오트 수 해저배관(Well-insulated pipeline)}

낮은 비오트 수에 대한 해석을 수행하기 위해 폴리프로필렌 (Polypropylene)으로 단열된 해저배관을 설정하여 Proposed formula 계산 및 수치해석을 수행하였다. 해저배관과 단열재 및 해저지반의 물성치는 Table 6과 같으며 비오트 수는 1.99 이다.

본 해저배관의 결과는 Fig. 12와 같다. 매립되지 않았을 때의 총괄열전달계수는 약 $10 \mathrm{~W} / \mathrm{m}^{2} \mathrm{~K}$ 이며 $200 \%$ 매립 되었을 때 약 $2.4 \mathrm{~W} / \mathrm{m}^{2} \mathrm{~K}$ 의 총괄열전달계수 결과를 확인 할 수 있었다. Proposed formula 계산 결과와 수치해석 결과의 차이는 $6.3 \%$ 를 초과하지 않았다.

Table 6 Properties of low biot number pipe and soils

\begin{tabular}{cccc}
\hline $\begin{array}{c}\text { Subsea pipe } \\
\text { and } \\
\text { multi-layered soils }\end{array}$ & $\begin{array}{c}\text { Subsea pipe } \\
\text { diameter } \\
{[\mathrm{m}]}\end{array}$ & $\begin{array}{c}\text { Depth of } \\
\text { layer } \\
{[\mathrm{m}]}\end{array}$ & $\begin{array}{c}\text { Thermal } \\
\text { conductivity } \\
{[\mathrm{W} / \mathrm{mK}]}\end{array}$ \\
\hline Pipe inner diameter & 0.4826 & - & 51 \\
Pipe outer diameter & 0.508 & - & 0.22 \\
Polypropylene & 0.552 & - & 1.31 \\
Soil layer 1 & - & $0 \sim 0.4$ & 1.4 \\
Soil layer 2 & - & $0.4 \sim 1.6$ & 1.6 \\
Soil layer 3 & - & $1.6 \sim \infty$ & \\
\hline
\end{tabular}

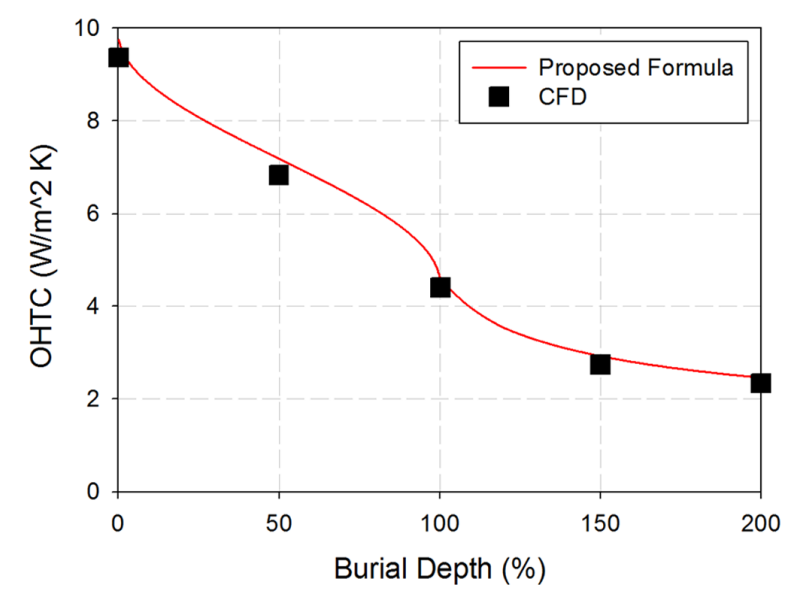

Fig. 12 OHTC result of low biot number of pipe

\section{2 해석 케이스 2 : 다양한 다층지반 구성}

두 번째로 한 가지 해저배관을 기준으로 다양한 다층지반에 대한 해석을 실시하였다. 먼저 3층으로 구성된 해저지반의 각 층의 열전도율을 변경하여 해석을 실시하였고 다음으로 두께
및 지반 층 개수가 다른 조건의 해석을 실시하였다.

5.2.1 다른 열전도율을 가지는 각 지반 충(Scenario 1과 2) 층의 두께가 일정한 다층지반에 각 층의 열전도율을 변경하 여 해석을 수행하였다. 본 시나리오 1 과 시나리오 2 는 중간 크 기 비오트 수의 해저배관을 사용하였으며 해석 케이스 1 의 다 층지반 층 개수 및 층 두께를 설정, 열전도율을 변경하여 해석 을 수행하였다. 다층지반의 열전도율 구성은 Table 7과 같다.

Table 7 Properties of Scenario 1 and Scenario 2

\begin{tabular}{cccc}
\hline \hline \multirow{2}{*}{$\begin{array}{c}\text { Multi-layered } \\
\text { soils }\end{array}$} & \multirow{2}{*}{$\begin{array}{c}\text { Depth of layer } \\
{[\mathrm{m}]}\end{array}$} & \multicolumn{2}{c}{ Thermal conductivity [W/mK] } \\
\cline { 3 - 4 } Layer 1 & $0 \sim 0.4$ & Scenario 1 & Scenario 2 \\
Layer 2 & $0.4 \sim 1.6$ & 1.4 & 1.31 \\
Layer 3 & $1.6 \sim \infty$ & 1.6 & 2.75 \\
\hline
\end{tabular}

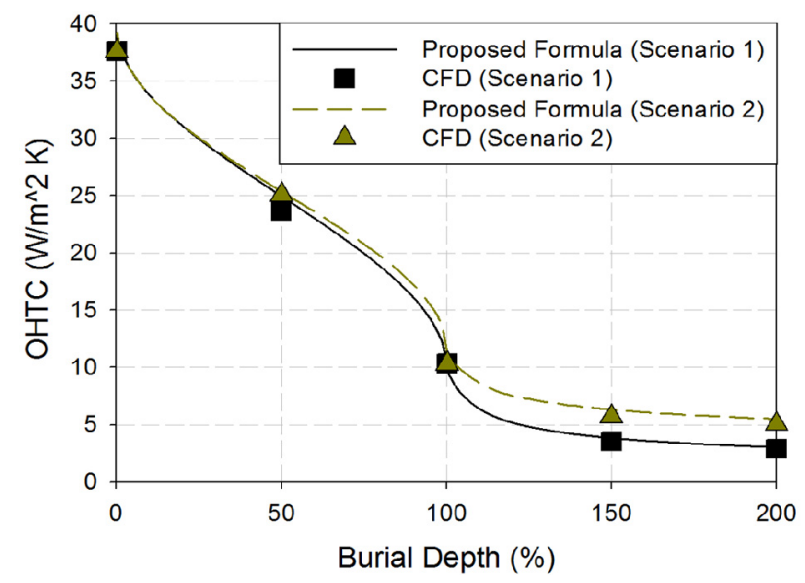

Fig. 13 OHTC results of Scenario 1 and Scenario 2

본 해석 결과는 Fig. 13과 같다. 시나리오 1 과 시나리오 2 의 Proposed formula 계산결과와 수치해석 결과의 평균 오차는 약 $6 \%$ 의 결과를 확인 할 수 있었다.

두 시나리오는 매립깊이 $100 \%$ 까지는 거의 유사한 경향을 확 인 할 수 있는데 이는 일부 매립된 해저배관의 경우 해수가 해 저배관의 총괄열전달계수에 지배적인 요인으로 작용하기 때문 이다. 또한 두 시나리오 결과는 완전매립 즉 매립깊이 $100 \%$ 에서 $200 \%$ 까지 차이를 확인 할 수 있는데, 이는 매립깊이가 깊어질수 록 해저배관의 총괄열전달계수에 해저지반이 지배적인 요인으 로 작용하기 때문이다. 매립깊이 $200 \%$ 에서 시나리오 1 과 시나리 오 2의 등가열전도율 $\left(k_{\text {equiv }}\right)$ 은 각각 $1.4756 \mathrm{~W} / \mathrm{m}^{2} \mathrm{~K}, 2.8667 \mathrm{~W} / \mathrm{m}^{2} \mathrm{~K}$ 이며 등가열전도율이 큰 다층지반에 매립된 시나리오 2 가 시나 리오 1 에 비해 총괄열전달계수 결과가 높게 나타났다.

\subsection{2 다른 두께를 가지는 지반 충(Scenario 3과 4)}

중간 크기 비오트 수의 해저배관이 다양한 두께의 층으로 구 성된 다층지반에 매립되었을 때를 가정하여 해석을 실시하였다. 다층지반의 두께 및 열전도율 구성은 Table 8 과 같으며 시나리 오 3 은 세 개의 층으로 구성하였다. 그리고 시나리오 4 는 4 개의 
Table 8 Properties of Scenario 3 and Scenario 4

\begin{tabular}{ccccc}
\hline \hline \multirow{2}{*}{$\begin{array}{c}\text { Multi-layered } \\
\text { soils }\end{array}$} & \multicolumn{2}{c}{$\begin{array}{c}\text { Depth of layer } \\
{[\mathrm{m}]}\end{array}$} & \multicolumn{2}{c}{$\begin{array}{c}\text { Thermal conductivity } \\
{[\mathrm{W} / \mathrm{mK}]}\end{array}$} \\
\cline { 2 - 5 } & Scenario 3 & Scenario 4 & Scenario 3 & Scenario 4 \\
\hline Layer 1 & $0 \sim 0.4$ & $0 \sim 0.4$ & 1.31 & 1.31 \\
Layer 2 & $0.4 \sim 2.0$ & $0.4 \sim 1.5$ & 1.4 & 1.6 \\
Layer 3 & $2.0 \sim \infty$ & $1.5 \sim 2.0$ & 1.6 & 2.75 \\
Layer 4 & - & $2.0 \sim \infty$ & - & 4.44 \\
\hline
\end{tabular}

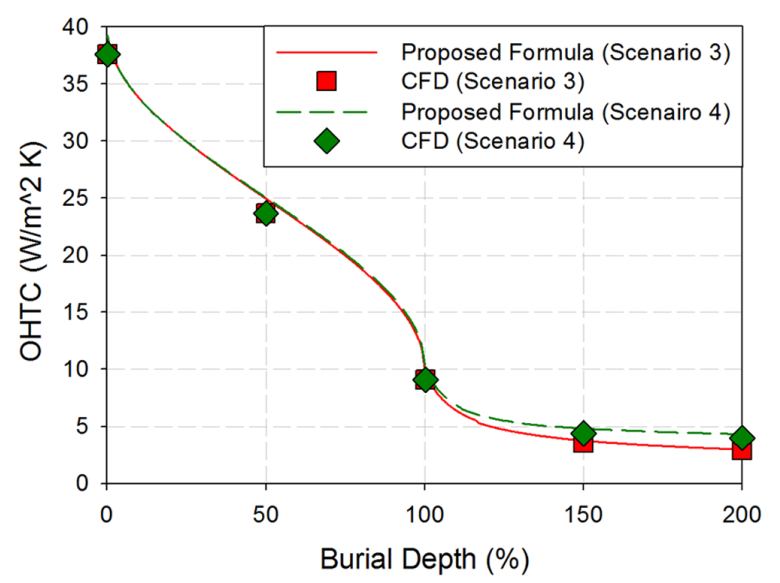

Fig. 14 OHTC results of Scenario 3 and Scenario 4

층으로 구성하였다. 해석결과는 Fig. 14와 같다. 시나리오 3 및 시나리오 4 의 매립깊이 $0 \%, 50 \%, 100 \%, 150 \%, 200 \%$ 에서 Proposed formula 계산결과와 수치해석 결과를 비교했을 때 평 균오차는 각각 $5.5 \%, 7.04 \%$ 으로 나타났다.

\section{6. 결 론}

본 논문은 기존 매립된 해저배관의 총괄열전달계수 이론식을 검토하였고, 실제 해저지반이 다층 지반 즉, 다양한 열전도율을 가지는 층으로 구성된 점에 착안하여 기존 해저배관 총괄열전 달계수 이론식 중 Zakarian이론식(Zakarian et al., 2012)을 토대로 변형한 식을 제안하였으며 Proposed formula라 명명하였다. 이를 위해 다층 지반의 열전도율은 Fourier의 열전도법칙을 적용하였 으며 각각의 다른 열전도율을 가지는 다층 지반을 하나의 등가 열전도율로 환산하여 식에 적용시켰다.

Proposed formula을 검토하기 위해 상용수치해석 프로그램인 CFX v13.0을 사용하여 수치 해석적 실험을 수행하였다. 해저배 관의 총괄열전달계수는 모델의 온도분포가 일정한 온도를 유지 하는 정상상태 일 때 해저배관의 입구, 출구, 해저배관표면 등 의 온도를 측정하여 측정된 온도를 토대로 산정하였다.

Proposed formula의 적용가능성을 검토하기 위해 두 가지 케 이스에 대해 Proposed formula 계산 및 수치해석을 수행하였다. 첫 번째 케이스는 해저배관 벽의 열전달계수 및 해저지반의 열 전도율에 의해 결정되는 비오트 수를 기준으로 분류하였으며 세 가지 해저배관을 설정하였다. 해저배관은 높은 비오트 수(50 $<B i_{p}$ )에 해당하는 해저배관 즉 비오트 수가 약 146 인 경우의
해저배관, 비오트 수 $\left(4<B i_{p} \leq 50\right)$ 에 해당하는 중간크기 비오트 수 해저배관 즉 비오트 수가 약 9 인 해저배관 그리고 낮은 비오 트 수 $\left(B i_{p} \leq 4\right)$ 에 해당하는 해저배관 즉 비오트 수가 약 1.99 인 해저배관을 설정하였다.

Proposed formula 계산결과 및 수치 해석적 실험 결과를 비교 하였을 때 해저배관의 매립깊이 $0 \%, 50 \%, 100 \%, 150 \%, 200 \%$ 에 서 평균 $5 \%$ 이내의 오차를 가지는 것으로 나타났다. 따라서 Proposed formula는 다양한 비오트 수를 가지는 해저배관의 총 괄열전달계수 계산에 적용가능하다고 판단된다. 두 번째 케이 스는 다양한 다층지반 환경에서 Proposed formula의 적용 가능 성을 검토하기 위해 다른 열전도율을 가지는 지반 층에 대한 시나리오와 두께가 다르고 지반 층의 개수가 다른 다층지반의 시나리오를 설정하였다. 전체 시나리오의 매립깊이 $0 \%, 50 \%$, $100 \%, 150 \%, 200 \%$ 에서 평균 $6 \%$ 의 오차를 가지는 것으로 나타 났다. 따라서 Proposed formula는 다양한 다층지반 환경에서 해 저배관의 총괄열전달계수 계산에 적용가능하다고 판단된다.

본 논문은 다층 지반의 다양한 열전도율을 고려한 해저배관 의 총괄열전달계수 이론식을 제안하기 위해 수치 해석적 방법 으로 비교 검토하였으며 향후 실내모형실험을 통해 Proposed formula의 적용 가능성에 대한 보다 정밀한 검증연구를 진행 할 예정이다.

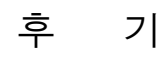

본 연구는 2017년 한국해양대학교 부산 산학융합지구조성사 업단 산학협력 R\&D과제“다층 지반을 고려한 매립된 해저배관 의 총괄열전달계수 산정”과제와 2017년 산업통상자원부 지원 산업핵심기술과제“ARC7 극지환경용 해양플랜트 내빙구조 설계 기술 개발’과제의 지원으로 수행된 결과임.

\section{References}

ANSYS Inc., 2010a. ANSYS CFX Theory Guide. ANSYS v130, Canonsburg.

ANSYS Inc., 2010b. ANSYS CFX Tutorials. ANSYS v130, Canonsburg.

Bai, Y., Bai, Q., 2005. Subsea Pipelines and Riser. 1st edition, Elsevier Ltd., Kidlington, Oxford.

Bai, Y., Niedzwecki, J.M., 2014. Modeling Deepwater Seabed Steady-state Thermal Fields around Buried Pipeline Including Trenching and Backfill Effect. Computers and Geotechnics, 61, 221-229.

Carslaw, H.A., Jaeger, J.C., 1959. Conduction of Heat in Solides. 2nd edition, Clarendon Press, Oxford.

Hamdham, B.G., Clarke, B.G., 2010. Determination of Thermal Conductivity of Coarse and Fine sand Soils. Proceedings of World Geothermal Congress, Bali, Indonesia.

Holman, J.P., 2009. Heat Transfer. $10^{\text {th }}$ edition, McGraw-Hill, New York.

Huminic, G., Huminic, A., 2013. Numerical Study on Heat Transfer 
Characteristics of Thermosyhon Heat Pipes using Nanofluids. Energy Conversion and Management, 76, 393-399.

Morud, J.C., Simonsen, A., 2007. Heat Transfer from Partially Buried Pipes. $16^{\text {th }}$ Australasian Fluid Mechanics Conference, Gold Coast, Australia.

Oh, D.-W., Park, J.M., Lee, K.H., Zakarian, E., Lee, J., 2014. Effect of Buried Depth on Steady-state Heat-transfer Characteristics for Pipeline-flow Assurance. SPE Journal, 19(06), 1,162-1,168.

Ovuworie, C., 2010. Steady-State Heat Transfer Models for Fully and Partially Buried Pipelines. CPS/SPE International Oil and Gas Conference and Exhibition, Beijing, China.

Papukchiev, A., Buchholz, S., 2017. Validation of ANSYS CFX for Gas and Liquid Metal Flows with Conjugate Heat Transfer within the European Project THINS. Nuclear Engineering and Design, 312, 338-350.
Park, D.S., Seo, Y.K., 2017. Experimental and Numerical Methods for Thermal Conductivity of Backfill Soils for Subsea Pipeline. Journal of Ocean Engineering and Technology, 31(2), 103-110.

Yoon, S., Lee, S.P., Go, G.H., Xue, J., Park, H., Park, D.W., 2014, Thermal Transfer Behavior in Two Types of W-shape Ground Heat Exchangers Installed in Multilayer Soils. Geomechanics and Engineering, 6(1), 79-98.

Xu, C., Yu, B., Zhang, Z.W., Zhang, J.J., Wei, J.J., Sun, S.Y., 2010. Numerical Simulation of a Buried Hot Crude Oil Pipeline During Shutdown. Petroleum Science, 7(1), 73-82.

Zakarian, E., Holbeach, J., Morgan, J., 2012. A Holistic Approach to Steady-State Heat Transfer From Partially and Fully Buried Pipelines. Offshore Technology Conference, Huston. 